Marquette University

e-Publications@Marquette

College of Education Faculty Research and

Publications

Education, College of

3-1-2004

The Influence of Accelerated Reader on the Affective Literacy Orientations of Intermediate Grade Students

\author{
Marla H. Mallette \\ Southern Illinois University Carbondale \\ Bill Henk \\ Marquette University, william.henk@marquette.edu \\ Steven A. Melnick \\ Pennsylvania State University
}

Accepted version. Journal of Literacy Research, Vol. 36, No. 1 (March 2004): 73-84. DOI. (C) 2004 SAGE Publications. Used with permission.

Bill Henk was affiliated with the Southern Illinois University - Carbondale at the time of publication. 


\title{
The Influence of Accelerated Reader on the Affective Literacy Orientations of Intermediate Grade Students
}

\author{
Marla H. Mallette \\ Southern Illinois University \\ Carbondale, IL \\ William A. Henk \\ Southern Illinois University \\ Carbondale, IL \\ Steven A. Melnick \\ Pennsylvania State University-Capital College \\ Harrisburg, $P A$
}

\begin{abstract}
Although the highly popular Accelerated Reader (AR) book reading incentive program claims to motivate children of all reading ability levels, very little independent empirical research has examined this assertion. To help fill this void, we used two related three-factor mixed designs with Method (AR vs. Control), Gender, and either Grade Level(fourth vs. fifth) or Reading Ability (high vs. low) to explore AR's influence on the reading attitudes and selfperceptions of children in two comparable school districts. The analyses indicate that AR positively influenced academic reading attitudes, but not recreational ones, and that it negatively influenced two types of selfperceptions in low achieving male readers. These findings and others of consequence are discussed along with implications for future research.
\end{abstract}

In recent years several computer-based literacy "programs" have been adopted by schools in attempts to increase students' 
reading achievement and motivation as well as to integrate technology into the curriculum (Biggers, 2001). Foremost among these commercial products is Accelerated Reader $(A R)$, a program claimed by its developers to be the most popular pre-K to grade 12 reading software in the nation and one whose features reportedly inspire children of all reading ability levels to strive to excel (School Renaissance Institute, 2001). As Pavonetti, Brimmer, and Cipielewski (2002-2003) note, $A R$ advocates maintain that the program encourages students to read more and better books which, in turn, will lead to increases in overall reading achievement and self-esteem. This assertion about $A R$ takes on added importance in light of findings reported by the National Reading Panel (2000) that there is no basis in scientifically based research that independent reading in school leads to increases in reading achievement.

Although the present study is not focused on reading achievement, the political climate created by the No Child Left Behind (NCLB) legislation places an extraordinary emphasis on scientifically based research. For this reason, it is our contention that the literacy community needs to conduct independent empirical research that examines claims touted as scientific, including those related to affect. In that spirit, our purpose is not to deconstruct $A R$, but rather to objectively analyze its influences on the reading attitudes and selfperceptions of fourth- and fifth-grade students.

\section{What is AR and How Does It Work?}

Accelerated Reader $(A R)$ is described as a "computerized information system" (Paul,2003, p. 6) that collects information on students as they read books and take multiple-choice quizzes to assess their comprehension. Currently $A R$ has practice quizzes for some 65,000 children's books. The questions are designed to tap literal comprehension, because these "types of questions yield adequate reliability and validity for the purpose of measuring reading practice" (Topping, 1999, p. 2)

The premise of $A R$ centers on what the developers describe as "guided independent reading" in which students and teachers receive immediate feedback that can be used to guide further reading. 
Students earn points for correct answers on these quizzes, with the number of points determined through ATOS $^{\text {TM }}$, a weighted formula that includes readability and the number of words in the book.

Students begin the program with the program's STAR ${ }^{\text {TM }}$ test as a way to determine their reading levels and to set their reading goals. The STAR ${ }^{\mathrm{TM}}$ test indicates student reading levels through vocabulary questions both in context (i.e., filling a word in a single sentence) and in connected text using a computerized adaptive branching technique. The levels are generally very broad, spanning an entire grade level. Students' reading goals reflect the number of points they are expected to earn in the marking period. This goal is set through the use of a formula that estimates how many points could be earned through 60 minutes of reading per day.

Noticeably missing from this description is direct reading instruction. It appears that the teacher's role in this program is essentially one of a monitor. The developers of the program argue that teachers modify their instruction based on student data, however, any provisions for adjusted instruction are not to take place during the 60 minutes of independent reading time.

\section{Why Study Accelerated Reader's Impact on Affect?}

The relative effectiveness of $A R$, both cognitively and affectively, is difficult to discern because very little high quality, independent scientific validation of the approach exists. Instead, the overwhelming majority of the reported $A R$ research includes problematic paradigms and designs including summary reports by school districts, mathfocused studies, ex post facto research, Master's theses, unpublished studies in electronic document reproduction services, evaluations by the company itself, and studies authored by researchers whose objectivity might be questioned(Topping \& Paul, 1999). For example, the company's most recent study (Paul, 2003) claims a causal relationship between guided independent reading and reading achievement. Yet the guidance consists merely of the students taking the practice quizzes upon completion of their book. In this study the measure to determine causation represents a confounding variable.

Journal of Literacy Research, Vol. 36, No. 1 (March 2004): pg. 73-84. DOI. This article is (C) SAGE Publications and permission has been granted for this version to appear in e-Publications@Marquette. SAGE Publications does not grant permission for this article to be further copied/distributed or hosted elsewhere without the express permission from SAGE Publications. 
That is, time spent reading was, in effect, used as both an independent and dependent variable.

Despite the lack of rigorous, independent evidence, the program continues to proliferate and the company prospers financially. Some schools have gone so far as to make $A R$ their complete reading program rather than a supplement, even though the developers caution against such an all-encompassing application. Using a program whose achievement effects are not known is dangerous, but an even greater long-term danger may lie in not knowing the impact of $A R$ on children's literacy affect. Some authors have argued on principle, for instance, that the competitive nature of $A R$ is likely to breed task avoidance, reduce internal motivation to read, and promote an unhealthy reliance on external motivation (Biggers, 2001). Interestingly, because the research on $A R$ has been so scant, these negative assertions by its critics cannot be verified any more convincingly than the company's claims of its motivational benefits. However, in a qualitative study of $A R^{\prime}$ 's relationship toreador and writer self-perceptions,

McCarthy (2001) found that in $A R$ classrooms children judged their own and other children's reading ability more on the basis of $A R$ 's color-coded reading levels and point system than on other more typically reported indicators of reading ability such as decoding, oral reading fluency, rate of reading, expressiveness, and frequency of reading (Henk \& Melnick, 1998). McCarthey (2001) suggests that considerably more data must be gathered to determine the program's overall effects on motivation. In this sense, a quantitative exploration of $A R$ 's relationship to children's attitudes and reader self-perceptions seemed to represent a natural extension of her work. To date, no large-scale studies have explored these phenomena. This gap in the professional literature is important because children's attitudes toward reading and how they feel about themselves as readers could clearly influence future literacy behavior. That is, attitudes and selfperceptions might affect whether reading would be sought or avoided, the amount of effort that would occur during reading, and how persistently readingcomprehension would be pursued (Henk \& Melnick, 1995). In short, the frequency and intensity of future reading engagements might hang in the balance. 
NOT THE PUBLISHED VERSION; this is the author's final, peer-reviewed manuscript. The published version may be accessed by following the link in the citation at the bottom of the page.

\section{Theoretical Framework}

This study is grounded in self-efficacy theory (Bandura, 1977, 1982; Schunk, 1984).The self-efficacy model, as we have interpreted it elsewhere (Henk \& Melnick,1995), predicts that children take four basic factors into account when forming the literacy self-perceptions that will influence their motivation to read (i.e., seeking to read, effort expenditure, and engagement). These four factors are Progress (how their current performance compares with past performance); Observational Comparison (how their performance compares with that of classmates); Social Feedback (verbal and nonverbal input from teachers, other children, and parents about their reading ability); and Physiological States (how they feel internally when engaged in the act of reading).

At least three of these factors (Progress, Observational Comparison, and Social Feedback) might be directly influenced by the very nature of $A R$. One need only visit an $A R$ classroom to see how these aspects of self-perception can come sharply into play. In these contexts, social comparative information, as defined by Ames (1992) and Stipek (1981), literally abounds. That is, a child's reading ability, rate of progress, and relative standing within the class becomes public information because artifacts of performance decorate the room and adjacent hallways. Moreover, teachers and students talk openly about the difficulty levels of the books that are being read (McCarthey, 2001), and the students appear to share information about their reading levels with classmates as one way of achieving greater social status. Whether intentional or not, $A R$ seems to promote the notion that moving up in reading level translates to moving up the social register. In this sense, then, literacy learning in $A R$ is clearly situated socially (Alvermann \& Guthrie, 1993). Unfortunately, the students and parents (and often the classroom teachers) seem to focus more on the stature of the $A R$ reading levels and on the acquisition of external rewards than on children's actual growth in reading.

Of special importance to the present study, $A R$ showcases progress in reading through its very public and visible nature, encourages observational comparisons with peers, and generates opportunities for social feedback to students from teachers, peers, and

Journal of Literacy Research, Vol. 36, No. 1 (March 2004): pg. 73-84. DOI. This article is (C) SAGE Publications and permission has been granted for this version to appear in e-Publications@Marquette. SAGE Publications does not grant permission for this article to be further copied/distributed or hosted elsewhere without the express permission from SAGE Publications. 
parents. For that matter, the program presents the opportunity for students to feel better internally about reading or improve what has been termed previously as physiological states. All or most of these factors interact in $A R$ contexts in ways that raise the specter of the negative effects that are often associated in the professional literature, rightly or wrongly, with competition in classrooms (Levine, 1983; Marshall \& Weinstein, 1984).

Beyond examining the impact of $A R$ on students' reading affect, the related factorsof reading ability, gender, and grade level bear closer examination as well. For instance, children of high and low reading ability might respond quite differently to the public recognition and emphasis on rewards that characterize $A R$. Interestingly, in that sense, $A R$ has the potential to encourage high achieving readers to feel more confident about their ability and less accomplished readers to doubt themselves further. McKenna, Kear, and Ellsworth (1995) have found significant differences favoring females with regard to reading attitudes, and these findings beg the question of whether those effects will be manifested in the $A R$ condition. These researchers also noted a consistent decline in both recreational and academic reading attitudes as children progressed upwards through grade levels. Since no known previous study has formally disaggregated reader selfperception results according to gender or grade level, it seems especially appropriate to include these factors against the backdrops of $A R$ and reading ability.

The present study, then, attempted to answer the basic question: What is the influence of Accelerated Reader on the reading attitudes and self-perceptions of intermediate grade boys and girls of differing reading abilities?

\section{Method}

The reading attitudes and self-perceptions of 358 students in fourth $(N=167)$ and fifth $(N=191)$ grades in two school districts were compared. The two districts, which were geographically adjacent, possessed similar socioeconomic demographics, namely, both had low to moderate family incomes. In terms of district-wide reading achievement profiles, both schools evidenced nearly $60 \%$ of their fifth 
grade students meeting or exceeding the standards on the 2002 state assessment in reading

\section{Treatments}

Students in one set of district schools $(N=235)$ experienced $A R$ as their basic reading instructional program. In these schools, the $A R$ focus could be termed intense. Students at all grades were expected to participate in one full hour of $A R$ activities per day. At those times, teachers were required by the school district to engage only in $A R$ related events, and they were monitored for adherence to this expectation. For the most part, teachers read with children individually and otherwise prepared them for their quizzes by asking questions about the story. When time permitted, teachers helped children select books, but their primary instructional purpose was moving children through the computer-administered quizzes to obtain the appropriate number of points needed for the students to reach their goals.

The students in these classrooms had participated in $A R$ since the first grade. $A R$ was the central component of their reading curriculum. A few of the teachers in these grades found ways to integrate reading instruction into the content areas. For example, the teacher would read whole class novels in social studies or teach prereading strategies with content text. However, from classroom observations and conversations, it was clear that from the students' perspectives, $A R$ represented their instruction. Accordingly, students' report card reading grades were based solely on their $A R$ performance.

By contrast, children in the control school $(N=123)$ had been exposed to $A R$, but only in a limited way. Their primary instruction was literature-based and centered on using novel units. In this second school there was an agreed upon set of texts for each grade level. Students read these texts, usually as a whole group, in round robin fashion. In a few classrooms, the students were divided into groups that read different novels and completed commercially produced worksheets that focused on comprehension and vocabulary questions. The use of $A R$ in these classrooms varied in its frequency and intensity, yet in all classes it was an addition to the reading curriculum and occurred in relation to the amount of free time available in each 
setting. No student requirements or specific time periods were set aside for the program.

Overall, reading instruction in the control school could be described as varying considerably, and students had differing perspectives on $A R$ that depended on their experiences in specific classrooms. The teachers in fourth and fifth grades did teach reading, but their instructional approaches were quite different. Some teachers used $A R$ daily for 15-20 minutes per day, while other teachers only used it once or twice a week. Clearly, it was an auxiliary reading program for students; accordingly, $A R$ performance was not reflected in their grades for reading. Students in this school regarded $A R$ primarily as an opportunity to acquire points to purchase items from the school store.

\section{Design and Analysis}

Near the end of the 2001-2002 school year, students in both districts were administered two well-established standardized affective instruments, the Elementary Reading Attitude Survey (ERAS) (McKenna \& Kear, 1990) and the Reader Self-Perception Scale (RSPS) (Henk \& Melnick, 1995). These instruments yielded six dependent measures which included Academic Reading and Recreational Reading on the ERAS, as well as Progress, Observational Comparison, Social Feedback, and Physiological State son the RSPS. In effect, the design was a Non-Equivalent Control Group type in which the first measure was Normal Curve Equivalent (NCE) scores on the Iowa Test of Basic Skills (ITBS) (Riverside, 1996) comprehension subtest and the actual dependent measures consisted of the six affective measures represented by the ERAS and RSPS. The main independent variable was treatment, and it consisted of two types: Accelerated Reader and Control. A $t$-test was used to compare the initial reading ability of the treatment and control groups as measured by the ITBS scores, and although the differences were not significant $(t=1.60, p>.05)$, they did approach significance $(p=.10)$. Here the $A R$ group enjoyed a mean score advantage (58.6 vs. 54.9) that was large enough, given the known association between ability and affect, to suggest that subsequent use of covariance procedures would be desirable. The ITBS scores were also used both for covariation and stratification by ability

Journal of Literacy Research, Vol. 36, No. 1 (March 2004): pg. 73-84. DOI. This article is (C) SAGE Publications and permission has been granted for this version to appear in e-Publications@Marquette. SAGE Publications does not grant permission for this article to be further copied/distributed or hosted elsewhere without the express permission from SAGE Publications. 
in later analyses. The design configurations, factorial in nature, took various forms including stratification by reading ability, grade level, and gender.

More specifically, the overarching configuration was a $2 \times 2 \times 2$ mixed design in which the independent variables were treatment (Accelerated Reader vs. Control), Gender (female vs. male), and either Grade Level (fourth vs. fifth) using NCEs as a covariate in an ANCOVA procedure or Reading Ability (low vs. high) where groups were stratified into top and bottom thirds using NCE scores in an ANOVA procedure. For both major configurations, separate analyses were made for each of the six dependent measures, and the Newman-Keuls Multiple-Range Test was used for all post hoc analyses.

\section{Results}

A preliminary step in the data analyses was to determine the interrelationships among the dependent measures. Pearson ProductMoment correlations among these six measures were computed, and the coefficients ranged from .32 to .68 , all significant beyond the .001 level. The moderate shared variance $(10 \%$ to $46 \%)$ indicated that while self-perceptions and attitudes were surely related, each of the six scales clearly measured different aspects of affect.

Because the relationships between the dependent measures were significant, the comparative data were initially analyzed in a multivariate fashion. A MANOVA procedure using all six dependent measures was used to compare the $A R$ treatment with the Control condition. A significant effect was indicated by a Hotelling's T2value of $.85(p<.0001)$. Since significance existed, corresponding univariate $F$-tests were warranted for each dependent measure, and they revealed a significant effect for Academic Reading, $\mathrm{F}=15.65, p<$ .001 . In this instance, $A R$ produced higher attitudes toward Academic Reading than the Control condition.

For the Method by Grade by Gender three-way analysis, ANCOVA procedures were used as an additional statistical control because previous analyses suggested that ability differences approached significance. Main effects favoring $A R$ were again observed

Journal of Literacy Research, Vol. 36, No. 1 (March 2004): pg. 73-84. DOI. This article is (C) SAGE Publications and permission has been granted for this version to appear in e-Publications@ Marquette. SAGE Publications does not grant permission for this article to be further copied/distributed or hosted elsewhere without the express permission from SAGE Publications. 
for method on the Academic Reading scale $[F(1,326)=16.6, p<$ $.001]$, but not for any other dependent measure $(p>.05)$. Main effects also occurred for grade level in both attitudes toward Recreational Reading $(F=8.2, p<.005)$ and Academic Reading $(F=$ $14.9, p<.0001)$. In both cases, fourth graders were more positive in their responses than fifth graders. Based on the findings of McKenna et al. (1995) neither this grade level decline nor the Gender main effect favoring females for both Recreational $(F=21.4, p<.001)$ and Academic Reading attitudes $(F=10.8, p<.001)$ was unexpected. Gender differences were also noted for Social Feedback $(F=6.6, p<$ $.02)$ and Physiological States $(F=11.86, p<.001)$, and again, females demonstrated more positive affect than males on these scales. There were no significant first- or second-order interaction effects observed $(p>.05)$ for any of the dependent measures. It should be noted that, as a crosscheck, the data were also analyzed without covariation, and all of the effects manifested in a nearly identical fashion to the ANCOVA.

An ANOVA procedure was also used for the Method by Ability by Gender analysis. In this analysis, main effects were indicated for Academic Reading attitudes, $F(1,223)=14.6, p<.0001$, and for Social Feedback, $F=5.3(p<.02)$, but not for Recreational Reading $(p>.05)$. As expected, the main effect for Ability was significant for all six measures, with good readers feeling more positively than poor readers in terms of each type of reading attitude and self-perception. Gender effects were again observed for Recreational $(F=10.4, p<$ $.001)$ and Academic Reading $(F=6.4, p<.01)$, as well as for Social Feedback $(F=4.1, p<.05)$ and Physiological States $(F=5.08, p<$ $.03)$, with females indicating greater positive affect than males.

Of special note, however, was a significant first-order interaction between method and gender $(F=5.5, p<.02)$ for Observational Comparison, as well as two significant second-order interactions related to method, one for Progress $(F=9.0, p<.003)$ and one for Social Feedback $(F=4.4, p<.04)$. For the first-order interaction, females in the Control condition indicated significantly lower feelings about how their reading compared to classmates than either the females in $A R$ or the males in either condition. For the second-order interactions involving both Progress and Social Feedback, low 
achieving males in the $A R$ condition and low achieving females in the Control condition exhibited significantly lower reader self-perceptions (see Figures 1 and 2, respectively). Second-order interaction effects on the Progress scale of the Reader Self-Perception Scale. Secondorder interaction effects on the Social Feedback scale of the Reader Self-Perception Scale.

\section{Discussion}

The findings of the present study suggest that $A R$ positively influences attitude toward Academic Reading but not Recreational Reading. This result reliably occurred across multiple analyses and is not altogether surprising since, in the $A R$ program, students select books to read at their own reading levels and of their interest. Further, the literal nature of the quizzes makes them seemingly easy to pass, and such success would ostensibly contribute to positive attitudes.

However, when paired with levels of gender and ability, $A R$ differentially influenced reader self-perceptions as indicated by results on the Observational Comparison, Progress, and Social Feedback scales of the RSPS. Perhaps most significantly, low achieving male readers appear to hold lower reader self-perceptions for Progress and Social Feedback in the $A R$ condition, whereas low-achieving female readers hold lower self-perceptions for these scales in the Control condition. Moreover, females in general indicate lower self-perceptions in Observational Comparison in the control condition.

Although $A R$ did not live up to its developers' billing of motivating readers of all ability levels in this study, neither did it result in any detrimental effects for reading attitudes or self-perceptions in average and high-achieving readers. Interestingly, though, in light of the bold claims of $A R^{\prime}$ s advocates, the program could reasonably be expected to have resulted in significant increases in attitude toward Recreational Reading across reading ability levels, grade levels, and genders. Its seeming inability to do so, albeit no less effectively than the control condition, suggests that the program does not necessarily inspire children to read to any greater extent outside of school, a factor known to be highly associated with increased levels of reading achievement (Anderson, Wilson, \& Fielding, 1988). 
Apparently, the public nature of student performance in $A R$ and its focus on social comparative information is not detrimental to the reading self-perceptions of high and low-achieving females and highachieving males. However, $A R$ does appear to differentially influence the self-perceptions of low-achieving males in terms of Progress and Social Feedback dimensions. Given that girls tend to have better literacy self-perceptions than boys and that high readers tend to have better self perceptions than low readers, the implications of this finding are particularly acute. Taken together, these facts suggest that educators using $A R$ need to pay special attention to the affective orientations of low-achieving males. This group is generally in dire need of improved self-perceptions, apart from treatment, and so, if $A R$ is somehow contributing to lower reader self-perceptions, then the possibility exists that their reading achievement might be compromised as well.

While only speculation, the negative influence of $A R$ on these males, compared with their control counterparts, could very well be a result of the program's public, competitive nature. For instance, Wigfield and Guthrie (1997) found that boys are more motivated in literacy tasks by competition than girls. In the $A R$ environment, lowachieving males may simply be unable to compete effectively. In turn, their reading inadequacies would be reinforced repeatedly and publicly in an $A R$ context, making feelings of failure difficult to avoid.

Accelerated Reader is an extremely prominent commercial product, reportedly used in half of our nation's schools (Paul, 2003), and like any program, it requires validation of its cognitive and affective impact on children's reading profiles. Thus, literacy researchers need to conduct quasi-experimental research that examines both the attitudinal and achievement effects of $A R$ and the interrelationship between them. Additionally, more qualitative research (e.g., interview and observation) that examines in greater depth how children experience and interpret $A R$ is also needed. As a community of literacy professionals, we need to be more knowledgeable about programs of this kind and be able to consult with our public school colleagues more meaningfully about their empirical effects. The present study represents a modest step in achieving that goal.

Journal of Literacy Research, Vol. 36, No. 1 (March 2004): pg. 73-84. DOI. This article is (C) SAGE Publications and permission has been granted for this version to appear in e-Publications@ Marquette. SAGE Publications does not grant permission for this article to be further copied/distributed or hosted elsewhere without the express permission from SAGE Publications. 
NOT THE PUBLISHED VERSION; this is the author's final, peer-reviewed manuscript. The published version may be accessed by following the link in the citation at the bottom of the page.

\section{References}

Alvermann, D., \& Guthrie, J. (1993). Themes and directions of the National Reading Research Center. Perspectives in Reading Research, 1, 1-11.

Ames, C. (1992). Classrooms: Goals, structures, and student motivation. Journal of Educational Psychology, 84, 261-271.

Anderson, R. C., Wilson, P. T., \& Fielding, L. G. (1988). Growth in reading and how children spend their time outside of school. Reading Research Quarterly, 23, 285-303.

Bandura, A. (1977). Self-efficacy: Toward a unifying theory of behavioral change. Psychological Review, 84, 191-215.

Bandura, A. (1982). Self-efficacy mechanism and human agency. American Psychologist, 37,122-147.

Biggers, D. (2001). The argument against Accelerated Reader. Journal of Adolescent and Adult Literacy, 45, 72-75.

Henk, W. A., \& Melnick, S. A. (1995). The Reader Self-Perception Scale (RSPS): A new tool for measuring how children feel about themselves as readers. The Reading Teacher, 48, 470-482.

Henk, W. A., \& Melnick, S. A. (1998). Upper elementary-aged children's reported perceptions about good readers: A self-efficacy influenced update in transitional literacy contexts. Reading Research and Instruction, 38, 57-80.

Levine, J. M. (1983). Social comparison and education. In J. M. Levine \& M. C. Wang (Eds.), Teacher and student perceptions: Implications for learning (pp. 29-55). Hillsdale, NJ: Erlbaum.

Marshall, H. H., \& Weinstein, R. S. (1984). Classroom factors affecting students' self evaluation: An interactional model. Review of Educational Research, 54, 301-325.

McCarthey, S. (2001). The impact of classroom curriculum on students' perceptions of good readers and writers. In J. Hoffman, D. Schallert, C. Fairbanks, J. Worthy, \& B. Maloch (Eds.), Fiftieth Yearbook of the National Reading Conference (pp. 419-429).Chicago: National Reading Conference.

McKenna, M. C., \& Kear, D. J. (1990). Measuring attitude toward reading: A new tool for teachers. The Reading Teacher, 43, 626-639.

McKenna, M., Kear, D., \& Ellsworth, R. (1995). Children's attitudes toward reading: A national survey. Reading Research Quarterly, 30, 934-956.

National Reading Panel. (2000). Report of the National Reading Panel. Washington DC: National Institute of Child Health and Human Development. Paul, T. D. (2003). Guided independent reading: An examination of the reading practice database and the scientific $c$ research supporting guided independent reading as implemented in Reading Renaissance. Wisconsin Rapids, WI: Renaissance Learning.

Journal of Literacy Research, Vol. 36, No. 1 (March 2004): pg. 73-84. DOI. This article is (C) SAGE Publications and permission has been granted for this version to appear in e-Publications@Marquette. SAGE Publications does not grant permission for this article to be further copied/distributed or hosted elsewhere without the express permission from SAGE Publications. 
NOT THE PUBLISHED VERSION; this is the author's final, peer-reviewed manuscript. The published version may be accessed by following the link in the citation at the bottom of the page.

Pavonetti, L. M., Brimmer, K. M., \& Cipielewski, J. F. (2002-2003). Accelerated reader: What are the lasting effects on the reading habits of middle school students exposed to Accelerated Reader in elementary grades? The Reading Teacher, 46, 300-310.

Riverside Publishing Company, (1996). Iowa Test of Basic Skills. Itasca, IL: Author.

School Renaissance Institute. (2001, January-August). Supercharge your curriculum with Renaissance! [Brochure]. Wisconsin Rapids, WI:

Author.

Schunk, D. H. (1984). Self-efficacy perspective on achievement behavior. Educational Psychologist, 19, 48-58.

Stipek, D. (1981). Children's perceptions of their own and their classmates' ability. Journal of Educational Psychology, 73, 404-410.

Topping, K. (1999, November). Formative assessment of reading comprehension by computer. Reading Online. Retrieved November 28, 2002, from http://www. readingonline.org./critical/topping/rolarL.html

Topping, K., \& Paul, T. (1999). Computer-assisted assessment of practice at reading: A large-scale survey using Accelerated Reader data. Reading and Writing Quarterly, 15,213-231.

Wigfield, A., \& Guthrie, J. T. (1997). Relations of children's motivation for reading to the amount and breadth of their reading. Journal of Educational Psychology, 89, 420-432.

Journal of Literacy Research, Vol. 36, No. 1 (March 2004): pg. 73-84. DOI. This article is (C) SAGE Publications and permission has been granted for this version to appear in e-Publications@Marquette. SAGE Publications does not grant permission for this article to be further copied/distributed or hosted elsewhere without the express permission from SAGE Publications. 
NOT THE PUBLISHED VERSION; this is the author's final, peer-reviewed manuscript. The published version may be accessed by following the link in the citation at the bottom of the page.

\section{Appendix}

Figure 1

Second-order interaction effects on the Progress scale of the Reader Self-Perception Scale.

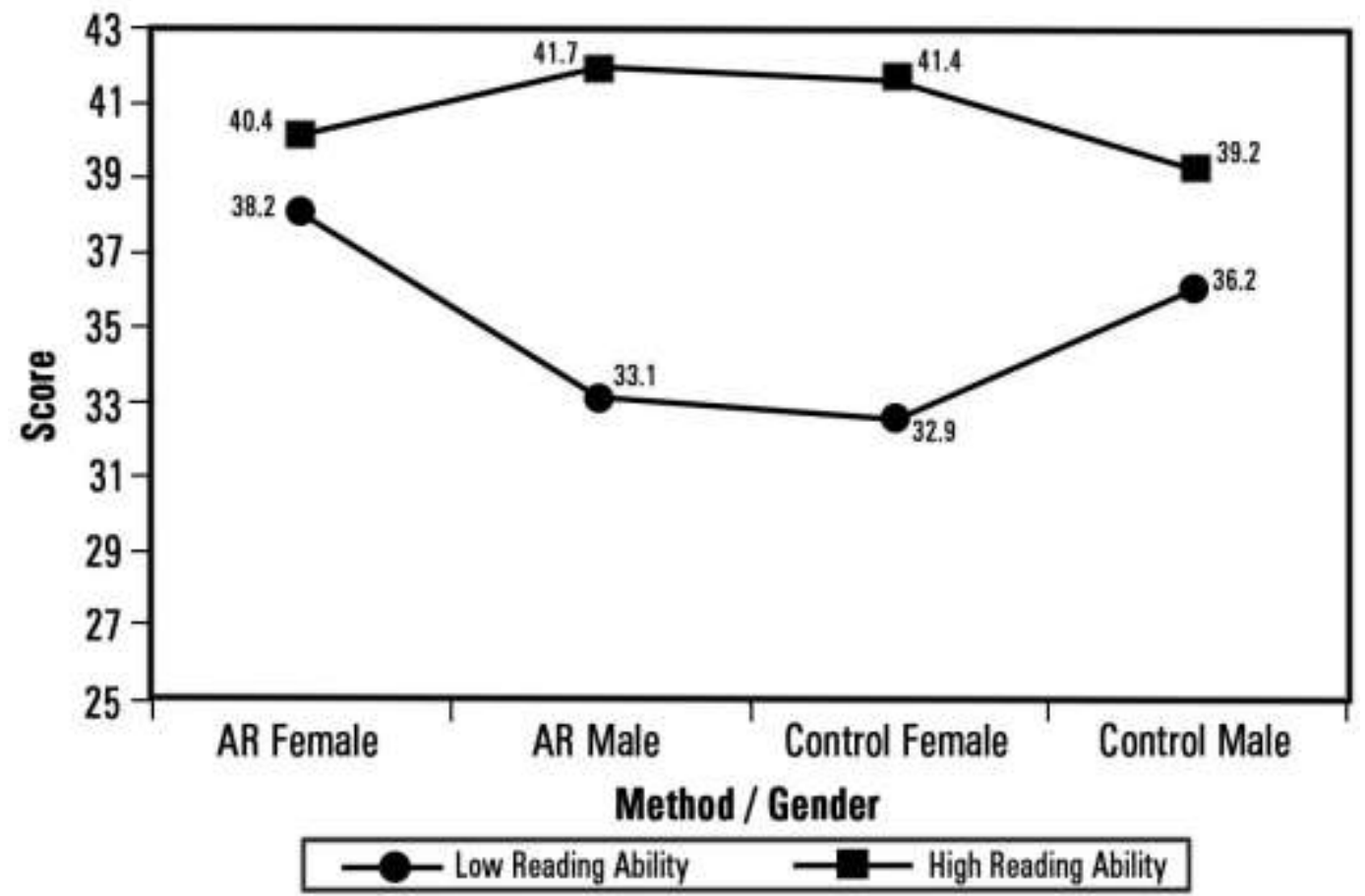

Journal of Literacy Research, Vol. 36, No. 1 (March 2004): pg. 73-84. DOI. This article is (C) SAGE Publications and permission has been granted for this version to appear in e-Publications@Marquette. SAGE Publications does not grant permission for this article to be further copied/distributed or hosted elsewhere without the express permission from SAGE Publications. 
NOT THE PUBLISHED VERSION; this is the author's final, peer-reviewed manuscript. The published version may be accessed by following the link in the citation at the bottom of the page.

Figure 2

Second-order interaction effects on the Social Feedback scale of the Reader Self-Perception Scale.

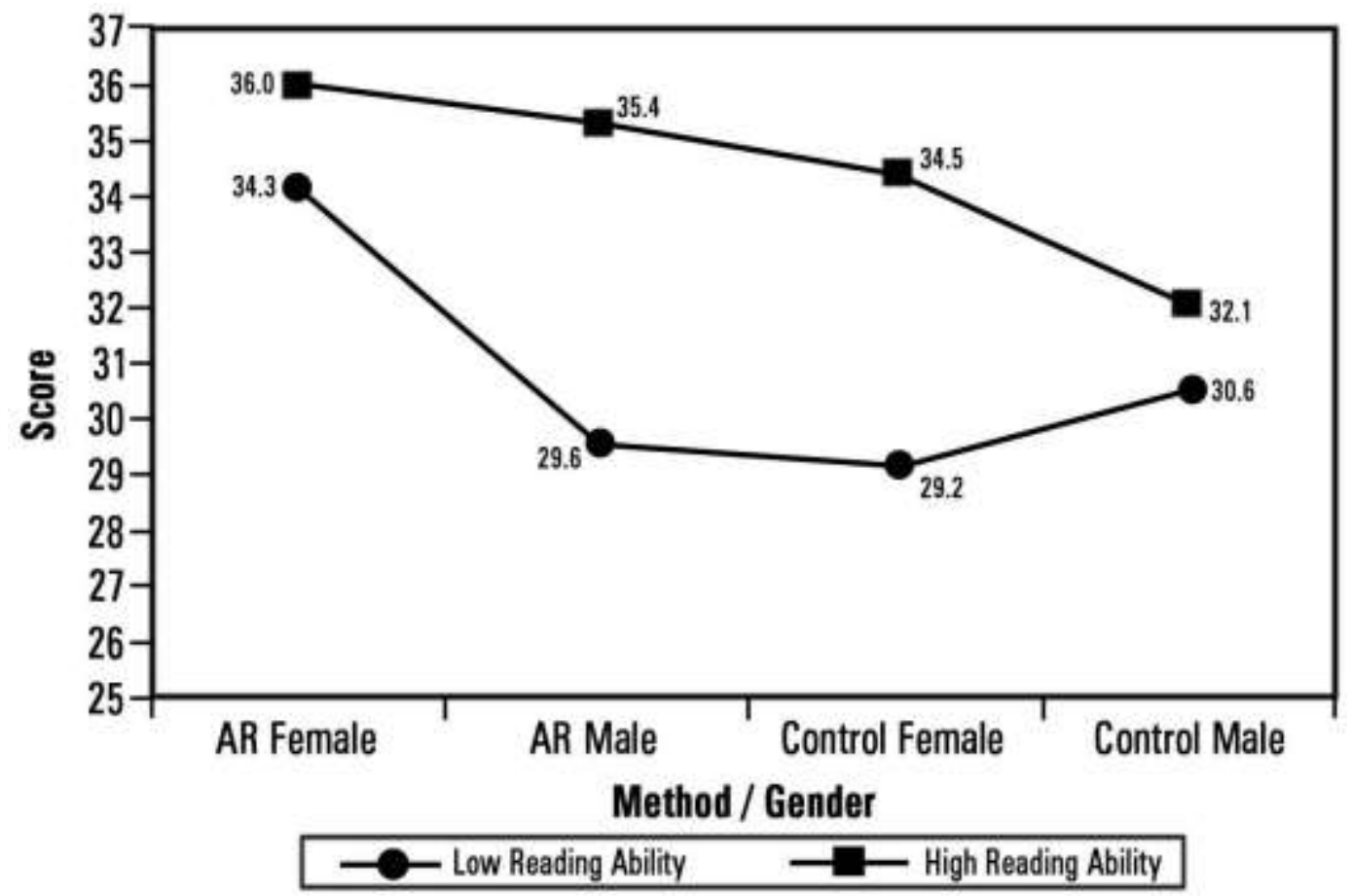

Journal of Literacy Research, Vol. 36, No. 1 (March 2004): pg. 73-84. DOI. This article is (c) SAGE Publications and permission has been granted for this version to appear in e-Publications@ Marquette. SAGE Publications does not grant permission for this article to be further copied/distributed or hosted elsewhere without the express permission from SAGE Publications. 